\title{
Pasifika pedagogies in an indigenous tertiary environment
}

Jay Hikuleo Ikiua, Te Wānanga o Aotearoa, New Zealand

\begin{abstract}
INTRODUCTION: This article examines how culturally appropriate teaching contributes to a positive learning experience for Pasifika students on the Bachelor of Bicultural Social Work degree programme at Te Wānanga o Aotearoa (TWOA), an indigenous tertiary institution in New Zealand dedicated to promoting access to education for Māori and others and delivering an educational experience based on indigenous principles and practice.
\end{abstract}

APPROACH: Teaching in a social work programme is explored through the lens of the Kaupapa Wānanga framework and Ngā Ūara (values) that form the foundational ideology of TWoA. It draws on the personal experiences of a social services educator using culturally responsive pedagogies that embrace the unique links of Polynesia-Pasifika peoples.

CONCLUSIONS: Culturally responsive pedagogy is vital for Pasifika students to feel valued and culturally connected.

KEYWORDS: Social work education; indigenous education; Pasifika peoples; pedagogy

AOTEAROA

NEW ZEALAND SOCIAL WORK 30(4), 28-39.

CORRESPONDENCE TO: Jay Hikuleo Ikiua

Jay.Ikiua@twoa.ac.nz
This article explores how culturally appropriate pedagogies integrated in classroom practice and the physical space contribute to a positive learning experience for Pasifika social work students at Te Wānanga o Aotearoa (TWoA), an Aotearoa New Zealand indigenous tertiary institution underpinned by Māori approaches. How TWoA's teaching and learning frameworks empower Pasifika social work students to value and express their own cultural identity and knowledge is explored.

I speak to the culturally responsive pedagogies of TWoA through my own Niue cultural lens and as an educator. For a Niue woman living in Aotearoa New Zealand, there are many similarities between Māori and Niue culture but there are also distinctions that make Pasifika people unique. I draw on my teaching experience, observations, and analysis and talanoa sessions with Pasifika students in seeking to serve the kaupapa of TWoA while valuing alternative ways of thinking about our world. Part of this journey is recognising the dominance of Western philosophy and pedagogy, not only in the lives of Pasifika people, but in my own. It is, further, coming to an awareness and an awakening of Oceanic perspective, knowledge, and wisdom that have been devalued or suppressed (Thaman, 2003, p. 2). The awakening is also to that of my own unconscious premise. Reclaiming a space of indigenous knowledge, not only of Mãori but also Pasifika, is to firstly acknowledge our whakapapa as people of Oceania, tuakanateina ${ }^{1}$ relationships and as descendants of Maui. Reclaiming indigenous knowledge is the acceptance of multiple wisdoms. 
In Aotearoa New Zealand, the terms Pasifika or Pasifika people are collective labels identifying seven Pacific nations: Niue, Tonga, Vanuatu, Fiji, Samoa, Tokelau and Cook Islands. Finau (2014) notes the Aotearoa New Zealand government, for bureaucratic purposes, has labelled Pasifika peoples despite controversies surrounding generalisations such as these. Labelling in this manner intentionally subsumes the existence of indigenous people into political systems as demonstrated in Canada (Alfred \& Corntassel, 2005). What should be consistently noted is that while the Pacific nations share similar beliefs, tradition and values, each possesses a unique cultural identity. However, TWoA also uses the term Pasifika in their analytics - so being specific and acknowledging the different nations and cultures of the Pacific in relation to enrolments makes a comparison impossible. Therefore, the term Pasifika will be used in this paper to identify the collective Pasifika representation as students participating in educational opportunities at TWoA.

The first section outlines the TWoA institutional context and the Pasifika student. Next, the essence of Kaupapa Wānanga is discussed. I then identify and discuss pedagogies identified by Pasifika students at TWoA as being culturally responsive. I have purposefully placed the literature review at the end, to acknowledge the value of indigenous knowledge and values that inform this kaupapa (Ruwhiu, 2018).

\section{Te Wānanga o Aotearoa and Pasifika}

TWoA has come a long way from its humble beginnings. Established in 1984, TWoA was created in response to the number of Māori not achieving in mainstream education. The training and education programmes offered through TWoA provide a holistic approach grounded on Māori values and principles. TWoA is now one of Aotearoa New Zealand's largest tertiary institutions and seeks to achieve whānau transformation through education.

There has been a steady stream of Pasifika students enrolling to study at TWoA. Pasifika have the third-highest enrolments behind Māori and European (see Figure 1). A large proportion of Pasifika students enrol in computer and business programmes. Tāmaki Mākaurau campus in Mangere, Auckland, has the largest number of Pasifika students across the country.

\section{Kaupapa Wānanga}

The Kaupapa Wānanga framework (Figure 2) was created to articulate the practices that are unique and distinct to TWoA. The framework was not to overtake or push aside existing Māori values within TWoA but to coexist in a space to support and uphold the practices of tikanga (procedure, guiding practices) Māori. The framework is encapsulated in the principles of:

- $\quad$ Kaitiakitanga - The constant acknowledgement that participants

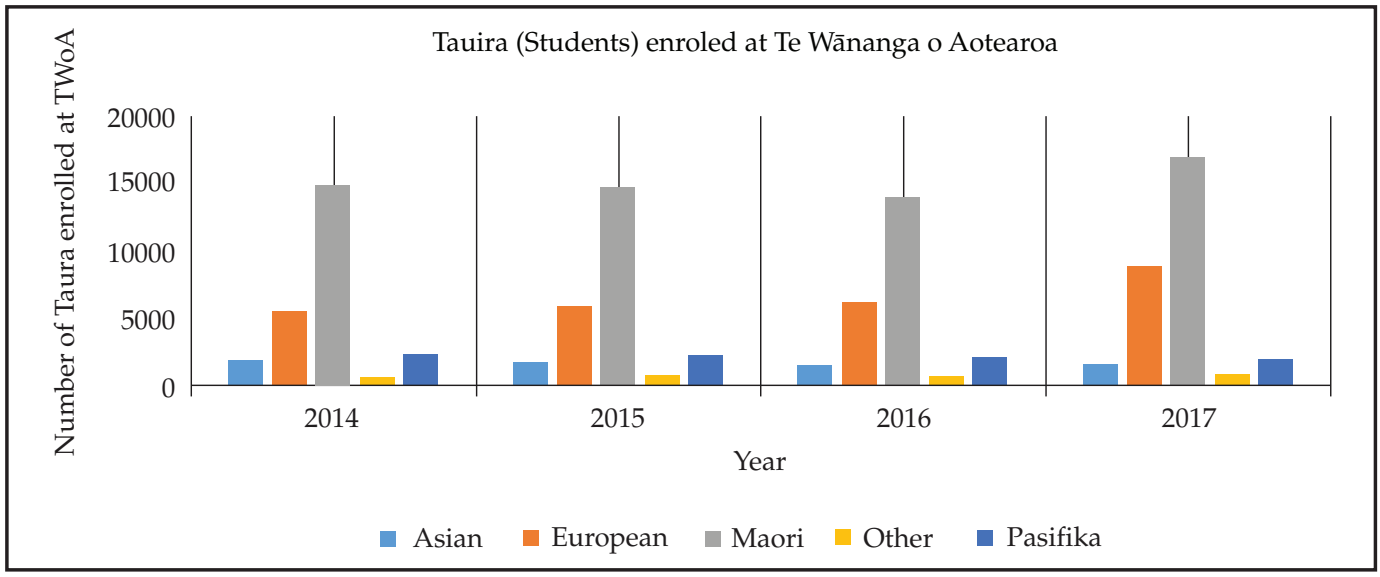

Figure 1. Pasifika students at Te Wānanga o Aotearoa (Watene, 2018). 


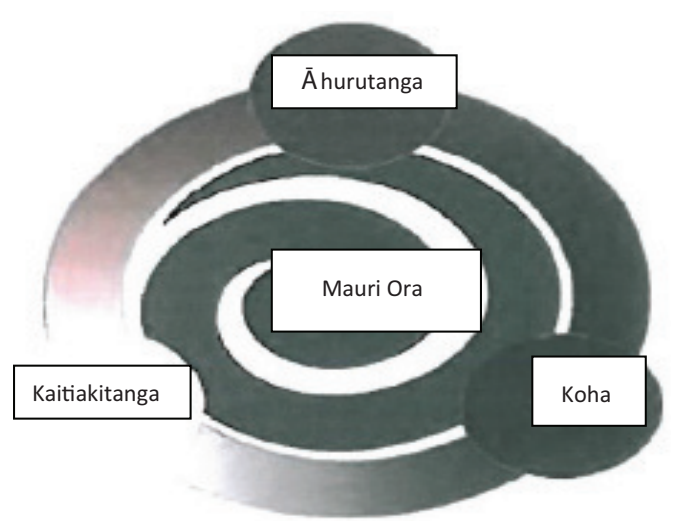

Figure 2. Kaupapa Wānanga framework (Hoani, 2012, p. 86) ${ }^{2}$.

(including Te Wānanga o Aotearoa as an institution) at any time and place are always engaged in relationships with others, their environments and kaupapa.

- Koha - The constant acknowledgement that quality spaces must be claimed and maintained to enable activities to be undertaken in an ethical and meaningful way.

- $\quad \bar{A} h u r u t a n g a-T h e ~ c o n s t a n t$ acknowledgement that valued contributions are to be given and received responsibly.

- $\quad$ Mauri Ora - The constant acknowledgement that pursuit of wellbeing is at the core of all Te Wānanga o Aotearoa kaupapa and activities. (TWoA, 2017, p. 8)

Kaupapa Wānanga guides how tauira (students) and kaimahi (staff) engage with each other.

Kaupapa Wānanga captures Māori epistemologies and exists "as a framework in which to anchor ourselves and restore our world order as we weave toward the future" (McRae, 2008, p. 198). According to Hoani (2012), Kaupapa Wānanga "complements and enhances existing values... [and are] guiding principles that contribute to our sense of purpose, meaning and destiny as a Wānanga an indigenous tertiary provider (p. 1). A visual depiction is provided in Figure 2.

Further to the Kaupapa Wānanga framework, TWoA is also underpinned by Ngā Uara, a set of values - Kotahitanga, Te Whakapono, Te Aroha and Ngā Ture presented in Figure 3. Ngā Uara upholds tikanga and guides best practice of engagement for all stakeholder relationships and what kaimahi at TWoA should aspire to.

Learning and applying Māori ways of knowing, doing and being through the

\section{Ngā Uara Our Values}
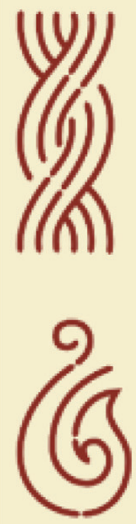

\section{Kotahitanga}

Unity amongst iwi and other ethnicities; standing as one

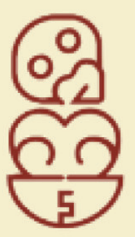

\section{Ngā Ture}

The knowledge that our actions are morally and ethically right and that we are acting in an honorable manner

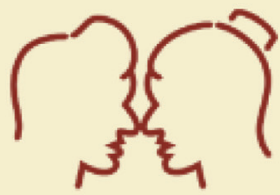

\section{Te Aroha}

Having regard for one another and those for whom we are responsible and to whom we are accountable to

Figure 3. Te Wānanga o Aotearoa Ngā Uara Values (Te Wānanga o Aotearoa, 2017, p. 6). 
application of Ngā Uara and Kaupapa Wānanga is filtered through my own cultural perspective and values. This is not to sanitise a "one size fits all approach" but to support Pasifika students to relate to, connect with, and broaden their knowledge of other indigenous knowledge.

Ngā Uara are interpreted by the individual's own lens and the application of practice but it must firstly be acknowledged how these frameworks are built on Te Ao Māori. In my practice I view Kotahitanga as unity alongside kaimahi to transform the lives of whānau through education. Ngā Ture is to act with respect within the realm of TWoA's tikanga. Te Whakapono is to stand with conviction in serving TWoA's kaupapa (purpose). Te Aroha - to serve with empathy and compassion.

The tenets of Kaupapa Wānanga state that, regardless of ethnicity, gender orientation or religious preference, TWoA tauira (students) do not leave their identities at the door. Tauira are encouraged to bring their worldviews, belief systems, values and culture knowledge to the classroom and the wider TWoA environment as shared by Hoani (2012).

\section{Culturally responsive pedagogies for Pasifika students at Te Wānanga o Aotearoa}

Culturally responsive pedagogy " $\ldots$ is teaching to the personal and cultural strengths through close interactions of ethnic identity, cultural background and student achievement" (Gay, as cited in Sleeter, 2012, p. 563). Sleeter argues that students of colour are well versed in their own cultural positioning and knowing and that by building on these capabilities good educational results will follow. Culturally responsive pedagogy for Pasifika students weaves their cultural values, beliefs and knowledge into their learning environments. According to the Aotearoa New Zealand government Pasifika Education Plan 20132017, Pasifika values are respect, belonging, service, family and relationships. Culturally responsive pedagogy specific to Pasifika students integrates culture into the learning environment (Ministry of Education, 2013).

Pasifika students become well versed in identifying and demonstrating the tenets of Kaupapa Wānanga in their everyday practice at TWoA. I have had many talanoa sessions (Vaioleti, 2006) - the sharing of stories, aspirations and values - with Pasifika Bachelor of Bicultural Social Work (BBSW) students throughout my teaching since 2015. Pasifika students come to a realisation that the principles of Kaupapa Wānanga are what they naturally do in their own physical and social environments and this prompts them to critically reflect on, explore and identify their own cultural values alongside Kaupapa Wānanga and to be confident in who they are. For example, I recall how a Pasifika student described that Āhurutanga (a sense of feeling safe in all environments) in the home as "eating mum's chop suey" (personal communication 11 March 2016). Or Kaitiakitanga (guardianship) as shared by Pasifika students is working in unity with the Pasifika community towards the preservation of cultural traditions and language.

The Ako Wānanga (the practice of learning and teaching) space at TWoA replicates a whānau space for all and enables Pasifika students to bring their cultural identity to TWoA. Ako Wānanga is TWoA's recipe for success and a culmination of narratives that reflect what works well through creating awesome learning experiences (TWoA, 2017). The culturally responsive pedagogy is demonstrated through what I call the magic of noho.

\section{The magic of noho}

The delivery of the BBSW degree at TWoA is noho based, meaning tauira (students) sleep over (for two nights) in the whare moe (sleeping area). Noho is not limited to the BBSW programme but is open to most programmes in TWoA. The noho delivery mode is more than providing a programme that is suitable for tauira who may not be 
able attend the standardised weekly classes. Noho weaves in Te Ao Māori where values are expressed: wairua (spiritual), tikanga (customs) and the organisation's kaupapa that defines and differentiates the Wānanga way.

At the end of the learning day, those of Māori and non-Māori cultures retire to the whare moe. It is here in the vicinity of the whare moe that the camaraderie, wairua (spirituality) and a certain reverence arises that unifies tauira and kaimahi. The evening is spent supporting tauira to prepare for group presentations, completing assignments and socialising over many cups of coffee. Or in my case, I wait for the usual suspects to do the take-away run where we have kai (food) - yet again. The dining tables and classrooms surrounding the whare moe serve as a refuge for tauira to laugh or cry as they share their personal journeys, worries, heartaches and tribulations.

Kaimahi and tauira succumb to the magic of noho. We relax together singing waiata (songs) and talanoa about bloopers or the humorous mishaps of the day. Sometimes we are the shoulders to cry on, the heart that feels and listens to the narratives of those who experience self-doubts about carrying on in the educational journey. We comfort and ease the worried minds of parent(s) who miss their tamariki (children). We take delight in sharing radical social work experiences and critical views of events that impact on the social work profession.

In my experience, the magic of noho is created through upholding of tikanga, engaging in meaningful social activities, strengthening collegial relationships, sharing of talanoa until the early hours of the morning and telling stories in the dark that reclaim the traditional indigenous practice of preserving cultural knowledge and histories (Vaioleti, 2006).

For the first noho of 2018, I arranged to take the BBSW year one class on a hikoi (walk) up the maunga Rangatuhi ${ }^{3}$ - otherwise known as Colonial Knob. The intention of the hikoi was to demonstrate a cultural pedagogy to demonstrate the principles of Kaupapa Wānanga and Ngā Uara.

The goal was to hikoi together as a class to see how far our feet or fitness levels would take us. The class walked with trepidation and some level of anxiety, not knowing how far the walk would go. I stopped the class every 10 minutes to reassess the situation and determine whether we continue with the hikoi or turn back. We accomplished what we could and, at the turning point, tauira (students) gave high fives, and encouraged and congratulated each other for making it so far. I did not realise the impact of the hikoi until tauira (including Pasifika) shared their reflections of the activity ${ }^{4}$ and the mauri round.

A mauri round is another indigenous culturally responsive practice to prepare for, reflect upon and embed learning. The mauri round is a standing practice in my class and other programmes at TWoA.

Tauira are seated in a circle and are given an opportunity to individually share their state of their mauri (wellbeing). This could be anything from how they are doing and how they felt about noho and the learnings. According to Pohatu (2002), mauri is vital to the wellbeing of relationships and informs how activities should be planned, progressed and monitored to achieve the intended goal.

The mauri round is a platform to build Whakawhanaungatanga (building respectful relationships) and trust as tauira share their state of being, the good and the bad, in an environment that is non-threatening and non-judgemental. According to Edwards, mauli (mauri) is known by the wider Polynesian family as the location of emotions and the very centre of the person (Edwards, 2014, p. 21).

Tauira shared the magic of noho through the mauri round and written work gathered from their reflective journals.

I was amazed at how good I felt after participating in the climb, I felt more 
comfortable with my class and strangely enough energized and a clearer mind

Noho was a great experience meeting everyone and settling in, created a close bond with most of my class mates, working together to hike Rangatuhi maunga and loads of compliments to each other and encouragement which made me feel great also having good conversations with each other learning about their interests and hobbies, family, heritage and culture.

The magic of noho creates learning experiences as tauira come together unified in their goal to complete the degree programme. As described by Pasifika students:

My honest opinion about first day of noho was long, tiring...class was awesome, trying to familiarise ourselves with names, getting to know each other. The bond our class shares with each other is amazing. The Saturday morning 3rd on March... all tauira to [sic] go up the maunga [Colonial Knob]. At first I was not all for it me being unfit and all. Walking up the maunga together was a great way of creating Whakawhanaugatanga. A class that has only known each other for a few days and some for the first time, but as experience walking up the maunga together it felt like Whānau, aiga, we were all in it together meaning no one got left behind.

Noho was a great experience meeting everyone and settling in, created a close bond with most of my class mates, working together to hike Rangatuhi maunga and loads of compliments to each other and encouragement which made me feel great also having good conversations with each other learning about their interests and hobbies, family, heritage and culture.

The hikoi can be best summed up by a Pasifika student: "we only got to tickle the feet of the maunga ... maybe next time we'll make it to the ankles" (personal communication, 3 March 2018).

\section{Kai}

Kai (food) is a social connecting that displays manaakitanga (caring about others) and aroha (love and compassion). Apiata-Vague (2011) affirms that food is a celebration of events big or small but that can also bring negative connotations through the offering of food between social worker and client. It can cross boundaries of professional relationships and at the same time break down the social barriers for reciprocity. Nguyen and Bowles highlight that to work effectively you must "first of all be a friend, only secondly a professional" (as cited in Apiata-Vague, 2011, p. 65). What better way to break down the barriers than through the sharing of kai?

Over the course of noho, kaimahi and tauira come together for shared kai. Kaimahi do not have a separate area with a Staff Only sign $^{5}$ unless they choose to retreat to the sanctuary of a more private space. Following kai, the social interactions continue where everyone is expected to perform the cleanup duties in the whare kai. The shared kai and space contribute to the whanau feeling of TWoA and does not differentiate between kaimahi and tauira. The atmosphere is buzzing as other tauira from different programmes come to know each other and engage in deep talanoa sessions. Tamariki are sometimes present as they come to share kai and grab quality moments with parent(s). What also contributes to the magic of noho is reciprocity. During noho, a group of tauira perform a waiata (song) to the catering kaimahi in acknowledgement of the preparation and hard work of kai in keeping the energy levels sustained throughout the day. There is no certain structure as everyone pitches in and helps - creating a sense of belonging to the physical space.

These social settings of noho and kai are embedded practices that contribute to 
culturally responsive pedagogies. The ako (learning and teaching) space is not limited to the classroom but is also through the sharing of talanoa outside the classroom. The magic of noho and kai creates the space that is attuned to Pasifika way of doing things. This is set by spiritual messages of karakia (prayer) and waiata (songs) that are familiar in Pasifika social and formal environments. Whilst this may seem disruptive to professional boundaries of separating learning/teaching spaces in Western institutions that "disempower" students (Kawagley \& Barnhardt, 2018), the teaching cultural pedagogy reinforces Pasifika social orientations in creating positive learning experiences.

Noho is akin to Place Based Education (PBE) (Penetito, 2009) approaches. PBE formalises connections for students to develop a love of the environment by placing an emphasis on teaching through culture rather than about culture. PBE is about identifying what the place means but also about relationships with the place. For Pasifika, connecting is not restricted to human relationships but to physical space and social scenes are attributes that are culturally appropriate for Pasifika students (Mila-Schaaf \& Robinson, 2010) In my experience, TWoA does this for Pasifika students where the culturally responsive pedagogies are a natural occurrence in respect of tikanga, Ngā Uara and Kaupapa Wānanga.

\section{The value of cultural knowledge for Pasifika students}

Cultural knowledge, known as indigenous knowledge, is "active participation through story-telling, sharing activities, and ways of understanding themselves in a natural environment and affording opportunities of relating and understanding each other" (Sam, 2011, p. 317). Sharing of cultural knowledge in heterogeneous classrooms and the wider educational institution creates robust learning experiences where Pasifika students can bring their entire selves and have freedom to culturally identity through art, poetry, oral history, songs, dress, kai and, more importantly, their own indigenous interpretations (Thaman, 2003). Sauni (2014) highlights how Pasifika educational success can be achieved through advancing Pasifika cultural capital in the classroom - allowing a Pasifika way of being.

What drives cultural knowledge in the classroom at TWoA is, firstly, Pasifika students tend to gravitate towards each other by seeking out commonality with peers. Pasifika students feel strengthened as a collective and reassured that they do not stand alone in their own worldview. Secondly, sharing cultural knowledge is further enhanced by Pasifika staff. Pasifika staff navigate the bicultural teaching space with respect and humility but are also encouraging of Pasifika students to be confident in their own positioning and world views through sharing their own cultural knowledge and being creators of their own learning frameworks. This practice validates cultural experiences and knowledge - Pasifika students willingly oblige and reciprocate these positive relationships by speaking of their own realities. Thirdly, Pasifika students also observe cultural humility where Pasifika staff share the learning space equally with all students and demonstrate tikanga respectfully. Cultural knowledge comes through when the learner and teacher sharing the learning space equally. The teacher does not hold all the knowledge. Both the teacher and learner learn from each other. Finally, Pasifika students as a collective create and add to the whānau feeling that is embedded in TWoA's character. Sharing of one's cultural knowledge strengthens one's resolve to achieve and strengthens self-confidence for Pasifika voices to be heard, and reinforces a positive learning environment (Savage et al., 2011; Mila-Schaaf \& Robinson, 2010).

Thaman (2003) argues that it is imperative for Pasifika students to share their cultural knowledge for not only "pedagogic reasons" (p. 11) but to improve class relationships 
and equal partnerships. More importantly, indigenous knowledge enriches the curriculum by adding multiple perspectives (Penitito, 2009).

\section{Māori and Pasifika relationships - People of Polynesia}

Ilonia stated "the only difference between you Maori and the rest of us Pacific Islanders [is] that you came on a waka and we came on a jet" (cited in Anae, Burgoyne, \& Iuli, 2006, p. 88). A statement that many Māori and Pasifika would find true and humorous. However, the synergies between Māori and Pasifika took place over thousands of years as descendants of Maui and from the Island of Hawaiiki. People of Polynesia left Hawaiiki a few hundred years before Māori thus cementing tuakana-teina relationships. Māori and Pacific peoples draw their history not only from the land but the ocean as voyagers. Somerville (2012) examines the two distinct communities of Māori and Pasifika relationships and how these relationships have been blurred through the diaspora and migration of Pacific peoples whilst these bicultural relationships are examined in a multicultural nation (Hill, 2010) and shaped by political and social developments. Somerville seeks to find where the connection takes place and how it is articulated. Māori and Pasifika people are spiritually linked and affiliate to land, ocean, culture, traditions and spirituality. We are also linked through the connection of indigenous knowledge.

My critical positioning, writing the first draft of this article, claimed that the Kaupapa Wānanga model and Ngā Uara were not Pasifika to claim. In saying this, I was denying how indigenous knowledge of Te Ao Māori ignited culturally sustainable pedagogy that is responsive and relevant to the cultural communities (Paris, 2012) namely for Pasifika students. Thaman (2003) claims that reclaiming indigenous knowledge is decolonising formal education. This is achieved though the experiences, narratives and wisdom of our people whether it be Māori or Pasifika.
Valuing indigenous knowledge between indigenous people enriches the learning experiences at TWoA. And this has been achieved through the culturally responsive pedagogies of physical spaces, the magic of noho and kai which are but a few of the positive learning experiences.

The literature review evidences the dire need for schools, teachers to be respectful and culturally responsive to cultural identity for Pasifika students (Chu, Arabella, \& Paurini, 2013). Pasifika students need to feel validated, valued and respected in any learning environment. For an indigenous institution such as TWoA, the kaupapa steers away from the dominant discourse prevalent in Western education systems and seeks to unapologetically decolonise mainstream education through cultural responsive pedagogies.

\section{Literature review}

The article seeks to draw attention to the application of indigenous Māori frameworks and the cultural teaching pedagogies for Pasifika students; to consciously understand the journey of how both cultures coexist in the same learning space. The literature review also explores Māori participation at secondary and tertiary levels. I deliberately bring in Māori research for various reasons. I believe it is necessary to add the voices that have for so long advocated for the Eurocentric education systems to open their eyes (if not already open) to the ongoing oppression of indigenous people. I also believe this article serves as a platform to highlight what is working well for, not only Pasifika at TwoA, but for Māori; in the hope that other tertiary institutions/educators can be creative and innovative in creating magical moments for all students. Acknowledging Māori through this medium concurs with Molisa (2016) who highlights that solving social and ecological issues to firstly support Māori in their fight for social justice and rebuild our connections is a priority. 
A considerable amount of research has been undertaken in Pasifika education. Pasifika early childhood development and transitioning is mentioned in the works of Meade, Puhipuhi, Foster-Cohen, and Anne Meade Associates (2003), and Taouma, Tapusoa, and Podmore (2013). Effective teaching practices and transitioning for primary and secondary schools are discussed in the publications of Hawk, Cowley, Hill and Sutherland (2002) and Hill and Hawk (2000). Additionally, tertiary participation, retention, cultural responsiveness and identity are explored (e.g., Chu, 2014; McCaffery, 2008; Porter-Samuels, 2013; Samu, 2006; Spiller, 2013). These researchers tell similar narratives: Pasifika students are underachieving and continue to struggle in mainstream education.

Māori are underrepresented at the tertiary level. The negative experiences during secondary school (Bishop \& Berryman, 2009) can have dire effects, particularly when Māori students become withdrawn, nonengaging/non-productive; resulting in many at a young age withdrawing from education systems.

Bishop and Berryman (2009) assert a key reason for Māori failing in a Eurocentric school system is the lack of cultural responsiveness. The learning space is individualistic, dominated by the teacher rather than a collective approach by sharing of power between the teacher and student. The authors further suggest that learning experiences be interactive and engaging to connect with the learner. These sentiments are also echoed in (MacFarlane, Glynn, Cavanagh, \& Batemean, 2007) who illustrate the importance of creating culturally safe schools for Māori students. In the current system Māori students are restricted and do not have the freedom to be culturally expressive and "...to be who they want to be" (p. 65).

Milne (2007) notes that education continues to push Māori learners into a realm of subordination, and little attention is given to cultural uniqueness, their values and personal freedom to articulate their own knowledge. This is further iterated by Tomlins-Jahnke (2007) who argues that "mainstream education" privileges a Western/Eurocentric system that fuels trauma and negative experiences for Māori and Pasifika learners.

The literature review for Pasifika education shared similar themes to those of Māori. Allen, Robinson, and Talafasi (2009) argue that Pasifika students were expected to conform and to fit into Western education paradigms that were unfamiliar and difficult to understand. The authors reiterate that, for successful educational outcomes, Pasifika students need to bring their own knowledge and being to the classroom. Samu (2006) writes about the inability of Aotearoa/New Zealand's school systems to be consciously aware and responsive to the diversity of learners. Too often the cultural identity of Pasifika students is dismissed and deemed insignificant. McKinley and Madjar's (2014) longitudinal research explores how Pasifika students experience transition from secondary to tertiary and how negative experiences hinder social progression.

Literature specific to Pasifika students at tertiary institutions speaks to the need for staff to be culturally responsive and for student support initiatives to be diverse to cater for the needs of Pasifika students. This has been accomplished by creating mentoring relationships (Chu, 2014) and enhancing cultural capital by creating Pacific-specific roles (McCaffery, 2008).

Mira (2014) examines how the experiences of Samoan woman at tertiary education in Aotearoa New Zealand strengthen or weaken their cultural identity. A research participant in Mira's study shared that "[P]acific voices were limited and seldom included" (p. 274).

Māori and Pasifika share similar narratives of an oppressive education system and the struggles encountered in tertiary institutions. 
Pasifika people migrated to Aotearoa New Zealand and entered into an educational system perpetuated by colonial behaviour and therefore, like Māori, education was bound to fail Pasifika students.

The literature gathered portrays the ongoing deficit practices in the education system impacting on Pasifika students. Empirical research articulates the narratives of Pasifika students who have been undervalued, marginalised and oppressed. There is very little research that speaks to the narratives of the aspirations and successes for Pasifika's students as explored by Mayeda, Keil, \& Dutton (2014). One of the few studies that does however, focus on the strengths is shared by Savage et al. (2011). The authors concur that teaching pedagogies should be culturally responsive to their students. They deliberately take a strengths-based view by focussing and enhancing Pasifika achievement by using the analogy of the zebras that can climb trees as opposed to discussing the why and the how.

This article provides only a snippet of Pasifika voices through reflective voices. However, identifying culturally responsive teaching pedagogies is a part of the magic that Penetito (2009) advocates for, and what others can learn from in raising good education outcomes for Pasifika students.

I have observed and assessed group presentations where Pasifika students apply traditional cultural practice with Māori kupu. The analogy that best describes the situations are the square pegs trying to fit into the round hole. Which, of course, cannot happen.

The study and research undertaken by So'o (2017) is the first to enquire about the Pasifika experiences at TWoA. The research explores tauira experiences of what contributes to success. He found 14 factors that contributed to success for Pasifika students, such as whānau supports. However, more ground-work is needed to further explore and identify
TWoA's commitment to uplift educational achievement for Pasifika. This example of cultural teaching pedagogy does not profess to know it all, nor is it claiming to have the absolute answer, however, sharing good practice is encouraged in the social work field and social work educators should model this approach.

\section{Conclusion}

Culturally responsive pedagogies are important to support learning for Pasifika students (Chu et al., 2013). Kaupapa Wānanga as a framework resonates with Pasifika students as they come to a realisation that these principles are very similar to their own way of knowing, doing and being. They are encouraged to learn and reflect on Te Ao Māori through these frameworks and sharing the indigenous knowledge in enhancing their own learning and valuing alternative ways of thinking. At the same time, Pasifika students should be encouraged to be architects of their own frameworks. I believe the unique learning tool is allowing space for Pasifika students to consciously take a lead in their learning space by sharing their cultural identity and values through Pasifika frameworks thus creating multiple perspectives that are enriching and by reproducing cultural capital in the BBSW space at TWoA.

Culturally responsive pedagogy, the magic of noho and the sharing of kai all help to create the whānau feeling for Pasifika students to feel valued and culturally connected to enjoy the TWoA experience. This serves as a reminder for educators that "the culture of the student cannot enter the classroom until it has first entered the consciousness of the teacher" (McKenzie \& Singleton, 2009, p. 5).

\section{Acknowledgement}

This article is dedicated to the Bachelor of Bicultural Social Work Students - achieving potential has no boundaries. Fakaue lahi mahaki for sharing your stories and 
enriching my journey. Kia monuina ha mutolu a tau fakaakoaoga.

\section{Notes}

${ }_{1}^{1}$ Tuakana-Teina has the power to eliminate barriers for the learner and the teachers. It allows indigenous people to reengage and participate in education through a methodology of knowledge sharing (Te Wānanga o Aotearoa, 2015).

${ }^{2}$ Text box inserted to clearly show the tenets of Kaupapa Wānanga framework - Ahurutanga, Koha, kaitiakitanga and Mauri Ora.

${ }^{3}$ Rangatuhi maunga is a local landmark of Porirua. The panoramic views from the top overlook Porirua Harbour, Cook Strait and Wellington, and on clear summer day, the South Island.

${ }^{4}$ Pasifika and Māori students on the BBSW Year 12018 programme consented to part of their Reflective Journal writing about the noho experience to be used for the article.

${ }^{5}$ This applies to Te Wānanga o Aotearoa - Porirua.

\section{References}

Alfred, T., \& Corntassel, J. (2005). Politics of identity - ix: Being Indigenous: resurgences against contemporary colonialism. Government and Opposition, 40(4), 597-614 Retrieved from http://www.jstor.org/stable/44483133

Allen, P., Robertson. J., \& Talafasi, L. (2009). In order to teach you I must know. In the Pasifika initiative: A professional development project for teachers. New Zealand Journal of Educational Studies, 44(2), 47-62.

Anae, M., Burgoyne, L., \& Iuli. L. (2006). The Polynesian Panthers: The crucible years, 1972-1974. Birkenhead, New Zealand: Reed Publishing.

Apiata-Vague, T. (2011). Social work and food: A discussion ANZSW Journals, 23(3), 63-70.

Chu, C. (2014). The development of mentoring relationships for Pacific students in a New Zealand university: Possibilities for leadership. In F. Cram, H. Phillips, P. Sauni, \& C. Tuagalu (Eds.), Māori and Pasifika higher education horizons (pp. 221-241), Bingley, UK: Emerald.

Chu, C., Arabella, I., \& Paurini, S. (2013). Educational practices that benefit Pacific learners in tertiary education. Retrieved from https://akoaotearoa.ac.nz/ download/ng/file/group-5330/educational-practices-thatbenefit-pacific-learners-in-tertiary-education.pdf

Edwards, S. (2014). Mauri in the context of ako Wānanga. UIA Magazine, pp. 21-22.

Bishop, R., Berryman, M., Cavanagh. T., \& Teddy, L. (2007) Te Kōtahitanga Phase 3 whānaungatanga: Establishing a culturally responsive pedagogy of relations in mainstream secondary school classrooms. Wellington, New Zealand: Ministry of Education. Retrieved from https://akoaotearoa.ac.nz/download/ng/file/group-5330/ fr-educational-practices-that-benefit-pacific-learners-intertiary-education.pdf

Bishop, R., \& Berryman, M. (2009). The Te Kotahitanga effective teaching profile. Set: Research information for teachers, 2(2).27-33

Finau, S. (2014). Collective label of people from the Pacific Ocean proper. In T. Black (Ed.), Enhancing mātauranga Māori and global indigenous knowledge (pp. 166-180). Wellington, NZ: NZQA.
Hawk, K., \& Cowley, E., Hill, J., \& Sutherland, S. (2002). The importance of the teacher/student relationship for Maori and Pasifika students. Set, Research Information for Teachers, 3, 44-66.

Hill, J., \& Hawk, K. (2000). Making a difference in the classrooms. Effective teaching practice in low decile, multicultural schools. Retrieved from https://www. educationcounts.govt.nz/publications/schooling/5459

Hill, R. S. (2010). Fitting multiculturalism into biculturalism Maori-Pasifika Relations in New Zealand from the 1960s. Ethnohistory. 57, 291-319.

Hoani, S. (2012). Kaupapa wānanga: A philosophy for life in Te Wānanga o Aotearoa WIPCE Conference Proceedings, Peru, 2011 (pp. 84-89). Te Awamutu, New Zealand, Te Wānanga o Aotearoa.

Kawagley, A., \& Barnhardt, R. (2018). Education indigenous to place: Western science meets native reality. Retrieved from http://www.ankn.uaf.edu/curriculum/

Macfarlane, A., Glynn, T., Cavanagh, T., \& Bateman, S. (2007). Creating Culturally-Safe Schools for Māori Students. The Australian Journal of Indigenous Education, 36(1), 65-76. doi:10.1017/ S1326011100004439

Mayeda, D. T., Keil, M., \& Dutton, H. D. (2014). You've gotta set a precedent: Māori and Pacific voices on student success in higher education. Retrieved from http://journals.sagepub.com/doi/ abs/10.1177/117718011401000206

McCaffery, J. (2008). Enhancing learning for Pasifika@UOA: A view from the inside. Retrieved from http://journals. sagepub.com/doi/pdf/10.1177/117718010800400113

Madjar, I., \& McKinley, E. (2014). From schools in lowincome communities to university: Challenges of transition for Māori and Pacific students Māori and Pasifika Higher Education Horizons (Vol. 15, pp. 241252): Emerald Group Publishing Limited.

McKenzie, R., \& Singleton, H. (2009, Oct). Moving from Pasifika immersion to Palangi Primary school. Knowing the learner is precious. Paper presented at the Exploring Effective Transitions Conference, Novotel, Hamilton.

McRae, L. (2008). Tihei Kaupapa Wānanga - What is the unique contribution made by Te Wānanga o Aotearoa? In R. Hunia (Ed.), Tokoa-te-nukuroa. Volume III, Reflections from within. (pp. 197-207), Te Awamutu, NZ: Te Wānanga o Aotearoa.

Meade, A., Puhipuhi, H., \& Foster-Cohen, S., \& Anne Meade Associates. (2003). Pacific early childhood education priorities for Pasifika early childhood education research. Wellington, New Zealand. Retrieved from https://www. educationcounts.govt.nz/publications/pasifika/5911

Mila-Schaaf, K., \& Robinson, E. (2010). Polycultural capital and educational achievement among NZ-born Pacific peoples. MAI Review, 1, 1-18.

Milne, A. (2007). Where am I in our schools "white spaces?" Social justice for the learners we marginalise. The Australian Journal of Indigenous Education, 36, 1

Ministry of Education. (2013). Pasifika education plan. Wellington, New Zealand: Author.

Mira, D. (2014). Samoan women in tertiary education. In F. Cram, H. Phillips, P. Sauni, \& C. Tuagalu (Eds.), Māori and Pasifika higher education horizons (pp. 271-290), Bingley, UK: Emerald. 
Paris, D. (2012). Culturally sustaining pedagogy: A needed change in stance, terminology, and practice. Educational Researcher, 41(3). doi/10.3102/0013189X12441244

Penetito, W. (2009). Place-based education: Catering for curriculum, culture and community. New Zealand Annual Review of Education, 18, 5-29. Retrieved from https:// www.victoria.ac.nz/education/research/nzaroe/issuesindex/2008/pdf/01text-penetito.pdf

Podmore, J., Tapusoa, E., \& Taouma, J. (2006). Samoan language and cultural continuity at an early childhood centre of innovation. Waikato Journal of Education, 12, 73-85.

Pohatu, T. and H (2002). Mauri-rethinking human wellbeing. Retrieved from http://www.rangahau.co.nz/assets/ Pohatu/Pohatu\%20T\%20Mauri.pdf

Porter-Samuels, T. (2013). Raising Pasifika achievement: Teacher cultural-responsiveness. Kairaranga, 14(2). Retrieved from http://files.eric.ed.gov/fulltext/EJ1025674.pdf

Ruwhiu, L. (2018). Kaupapa wānanga [Presentation]. Te Wānanga o Aotearoa, Porirua.

Sam, M. (2011). An indigenous knowledges perspective on valid meaning making: A commentary on research with the EDI and Aboriginal communities. Social Indicators Research. 103, (2) 315-325.

Samu, T. W. (2006). The "Pasifika umbrella" and quality teaching: Understanding and responding to the diverse realities within. Waikato Journal of Education, 12, 35-49.

Sauni, P. (2014). My sixth sense tells me. In F. Cram, H. Phillips, P. Sauni, \& C. Tuagalu (Eds.), Māori and Pasifika higher education horizons (pp. 135-146), Bingley, UK: Emerald.

Savage, C., Hindle, R., Meyer, L. H., Hynds, A., Penetito, W., \& Sleeter, C. E. (2011). Culturally responsive pedagogies in the classroom: indigenous student experiences across the curriculum. Asia-Pacific Journal of Teacher Education, 39(3), 183-198. doi:10.1080/1359 866X.2011.588311

Sleeter, C. E. (2012). Confronting the marginalisation of cultural responsive pedagogy. Retrived from https://s3.amazonaws.com/academia.edu. documents/35568511/2012

Sommerville, A. (2012). Once were Pacific Māori connections to Oceania. Minnesota, USA: University of Minnesota Press.

So'o, J. (2017). Pasifika tertiary students understanding of success (Unpublished Master's thesis), Whitireia Polytechnic, Porirua, New Zealand.

Spiller, L. T. (2013). Teachers' misunderstandings that affect the learning of their Pasifika students (Unpublished Master's thesis), Victoria University, Wellington, New Zealand.

Taouma, J; Tapusoa, E. and Podmore, VN. (2013). Nurturing positive identity in children: Action research with infants and young children at the A>oga Fasa Samoa, an early childhood Centre of Innovation [online]. Journal of Educational Leadership, Policy and Practice, 28, 1, 50-59.

Te Wānanga o Aotearoa. (2017). Kaupapa Wānanga. Te Manu. Retrieved from C:/Users/8277/Downloads/ TeManu-StudentHandbook2017\%20(7).pdf

Thaman, K. H. (2003). Decolonialisation Pacific Studies: Indigenous perspectives, knowledge, and wisdom in higher education. The Contemporary Pacific, 151, Spring, 1-17.
Tomlins-Janke, H. (2007). The place of cultural standards. Presented at American Education Research Association Annual Conference. Chicago, IL.

Vaioleti, T. (2006). Talanoa research methodology: A developing position on Pacific research. Waikato Journal of Education, 12, 21-35.

Watene, D. (2018). Pasifika enrolments at Te Wānanga o Aotearoa [unpublished raw data]. 